OPEN ACCESS

Edited by: Meixue Zhou,

University of Tasmania, Australia

Reviewed by:

Mohamed Magdy F. Mansour, Ain Sham University, Egypt

Mirza Hasanuzzaman,

Sher-e-Bangla Agricultural University,

Bangladesh

*Correspondence:

Fenghua Zhang

fenghuazhang2021@163.com

Specialty section

This article was submitted to

Plant Abiotic Stress,

a section of the journal

Frontiers in Plant Science

Received: 14 November 2021

Accepted: 04 January 2022

Published: 27 January 2022

Citation:

Wang $W$, Zhang F, Sun L, Yang $L$,

Yang $Y$, Wang $Y$, Siddique KHM and

Pang J (2022) Alkaline Salt Inhibits

Seed Germination and Seedling

Growth of Canola More Than Neutral

Salt. Front. Plant Sci. 13:814755

doi: 10.3389/fp/s.2022.814755

\section{Alkaline Salt Inhibits Seed Germination and Seedling Growth of Canola More Than Neutral Salt}

\author{
Weichao Wang ${ }^{1,2}$, Fenghua Zhang ${ }^{1 *}$, Lupeng Sun ${ }^{1}$, Lei Yang', Yang Yang ${ }^{1}$, \\ Yajuan Wang ${ }^{1}$, Kadambot H. M. Siddique ${ }^{2}$ and Jiayin Pang ${ }^{2}$ \\ ${ }^{1}$ The Key Laboratory of Oasis Eco-Agriculture, Xinjiang Production and Construction Crops, Shihezi University, Xinjiang, \\ China, ${ }^{2}$ The UWA Institute of Agriculture and School of Agriculture and Environment, The University of Western Australia, \\ Perth, WA, Australia
}

Salinity is a major constraint to crop growth and productivity, limiting sustainable agriculture production. Planting canola (Brassica napus L.) variety with salinity-alkalinity tolerance as a green manure on the large area of salinity-affected land in Xinjiang could alleviate feed shortage. To investigate the differential effects of neutral and alkaline salt stress on seed germination and seedling growth of canola, we used two salts at varying concentrations, i.e., $\mathrm{NaCl}$ (neutral salt at 100, 150, and $200 \mathrm{mM}$ ) and $\mathrm{Na}_{2} \mathrm{CO}_{3}$ (alkaline salt at 20,30, and $40 \mathrm{mM}$ ). To further explore the effects of $\mathrm{Na}^{+}$and $\mathrm{pH}$ on seed germination, we included combined of $\mathrm{NaCl}(0,100,150$, and $200 \mathrm{mM})$ and $\mathrm{pH}(7.1,8.0$, $9.0,10.0$, and 11.0). Shoot growth was promoted by low concentrations of $\mathrm{NaCl}$ and $\mathrm{Na}_{2} \mathrm{CO}_{3}$ but inhibited at high salt concentrations. Given the same $\mathrm{Na}^{+}$concentration, $\mathrm{Na}_{2} \mathrm{CO}_{3}$ inhibited seed germination and seedling growth more than $\mathrm{NaCl}$. The results showed that the main factor affecting seed germination and seedling growth is not $\mathrm{pH}$ alone, but the interaction between $\mathrm{pH}$ and salt ions. Under $\mathrm{NaCl}$ stress, canola increased the absorption of $\mathrm{K}^{+}, \mathrm{Ca}^{2+}$, and $\mathrm{Mg}^{2+}$ in roots and $\mathrm{K}^{+}$in leaves. However, under $\mathrm{Na}_{2} \mathrm{CO}_{3}$ stress, canola maintained a high $\mathrm{K}^{+}$concentration and $\mathrm{K}^{+} / \mathrm{Na}^{+}$ratio in leaves and increased $\mathrm{Ca}^{2+}$ and $\mathrm{Mg}^{2+}$ in roots. Our study showed that alkaline salts inhibit canola seed germination and seedling growth more significantly than neutral salts and salt species, salt concentration, and $\mathrm{pH}$ significantly affected on seed germination and seedling growth. However, $\mathrm{pH}$ affected seed germination and seedling growth mainly through an interaction with salt ions.

Keywords: salt stress, hydroponic, $\mathrm{pH}$ buffer systems, ion absorption and transportation, canola (Brassica napus L.)

\section{INTRODUCTION}

Soil salinization is a major constraint affecting crop growth and productivity, especially in arid and semi-arid regions (Parihar et al., 2015). On a global scale, more than 800 million ha of land, i.e., nearly $20 \%$ of the total arable land area and $>7 \%$ of the total land area, are affected by salinity (Shabala, 2013; Hakim et al., 2014). Xinjiang has the largest and most widely distributed area of salinity-affected soils in China (Yang et al., 2016; Zhao et al., 2019), with 31\% of cultivated land affected by varying degrees of salinization (Wang and Cheng, 2000). 
Soil salinization and alkalization frequently co-occur in soil, and the conditions in natural salt/alkaline soils are very complex. Studies have shown that salt stress is caused by neutral salts, and alkali stress is induced by alkaline salts (Lin et al., 2016). Neutral salts, such as $\mathrm{NaCl}$ and $\mathrm{Na}_{2} \mathrm{SO}_{4}$, and alkaline salts, such as $\mathrm{NaHCO}_{3}$ and $\mathrm{Na}_{2} \mathrm{CO}_{3}$, are the primary ion sources found in saline soils; $\mathrm{Na}^{+}, \mathrm{K}^{+}, \mathrm{Ca}^{2+}$, and $\mathrm{Mg}^{2+}$ are the main cations and $\mathrm{Cl}^{-}, \mathrm{NO}_{3}{ }^{-}, \mathrm{HCO}_{3}{ }^{-}, \mathrm{CO}_{3}{ }^{2-}$, and $\mathrm{SO}_{4}{ }^{2-}$ are the main anions. Indeed, studies have confirmed that alkaline salts damage plants more than neutral salts (Guo et al., 2015; Wang et al., 2017; Zhang et al., 2020; Lu et al., 2021). Therefore, comparing the differential response of plants to neutral and alkaline salt stress is important for improving the utilization of saline-alkaline soils for agricultural production (Wang et al., 2015).

Excessive salinity can have various adverse effects on plant, including ion toxicity, osmotic stress caused by $\mathrm{Na}^{+}$and $\mathrm{Cl}^{-}$, accumulating, and oxidative stress due to the over-production of reactive oxygen species (Lu et al., 2017; Causin et al., 2020; Saberi Riseh et al., 2021). Salinity causes intracellular ion imbalance and decreases $\mathrm{K}^{+}, \mathrm{Ca}^{2+}$, and $\mathrm{Mg}^{2+}$ concentrations in plant (NievesCordones et al., 2016; Assaha et al., 2017; Manishankar et al., 2018; Isayenkov and Maathuis, 2019; Arif et al., 2020; Shahzad et al., 2021). Intracellular $\mathrm{K}^{+}$and $\mathrm{Na}^{+}$homeostasis is essential for cell metabolism, with the $\mathrm{K}^{+} / \mathrm{Na}^{+}$ratio determining plant enzyme activation and osmotic adjustment (Assaha et al., 2017; Pivovarov et al., 2019). $\mathrm{Ca}^{2+}$ is an essential component of the middle lamella and cell walls, which can alleviate $\mathrm{Na}^{+}$toxicity and regulate ion absorption and transport (Amor et al., 2010; Feng et al., 2016). Therefore, preventing excessive $\mathrm{Na}^{+}$transport to shoots and maintaining high cytosolic ratios of $\mathrm{K}^{+} / \mathrm{Na}^{+}$and $\mathrm{Ca}^{2+} / \mathrm{Na}^{+}$are crucial for salt tolerance in plants. Canola is an important oil crop and an ideal phytoremediation species for the agricultural development of saline soils in China. China is one of four major canola production areas in the world. In 2017, the planting area reached 6.65 million ha $(19 \%$ of global area), with an annual yield of 13.3 million tons (17\% of global production) (Food and Agricultre Organization [FAO], 2017). In general, canola is sensitive to salinity stress (Bandehagh et al., 2011; Shokri-Gharelo and Noparvar, 2018), with seed germination and seedling growth stage as the most critical and sensitive periods for most plant species subjected to salinity (Guo et al., 2017). In Xinjiang, our research group developed a saline-alkaline tolerant canola cultivar that has been widely planted ( 0.4 million ha) as green manure in saline and alkaline land. Therefore, it is important to investigate the physiological mechanisms underlying its salt and alkaline tolerance.

So far, studies on salt stress in canola have been primarily focused on neutral salt $(\mathrm{NaCl})$, but limited studies on alkaline stress, especially the interaction between $\mathrm{pH}$ and salt concentrations, and its effect on seed germination and seedling growth. In this study, we investigated the exogenous application of neutral salt $(\mathrm{NaCl})$ and alkali salt $\left(\mathrm{Na}_{2} \mathrm{CO}_{3}\right)$ on seed germination, seedling growth, and the distribution of $\mathrm{Na}^{+}, \mathrm{K}^{+}$, $\mathrm{Ca}^{2+}, \mathrm{Mg}^{2+}, \mathrm{Cl}^{-}$, and $\mathrm{SO}_{4}{ }^{2-}$ in canola roots, shoots, and leaves. This study aimed to: (1) evaluate the effect of salt and alkali stresses on canola seed germination and seedling growth; (2) investigate the effect of salt and alkali stresses on the distribution of major saline-alkali ions in various canola plant parts; and (3) evaluate ion absorption and transport in canola plants under different saline-alkali stress conditions.

\section{MATERIALS AND METHODS}

\section{Plant Materials}

Canola (Brassica napus L.) cv. Huayouza 62 was used as the experimental material, due to its high tolerance to salinityalkalinity (Wang, 2020). The seeds were provided by Huazhong Agricultural University, China.

\section{Germination Experiment Stress Treatments}

The experiment was conducted at the Key Laboratory of Oasis Ecology Agriculture of Xinjiang Bingtuan, Shihezi University, Xinjiang, China in June 2018. Salt treatments, either as neutral salt $(\mathrm{NaCl})$ or alkaline salt $\left(\mathrm{NaHCO}_{3}\right)$, were imposed at six levels $(50,100,150,200,250$, and $300 \mathrm{mM})$ with little difference in $\mathrm{pH}$ (Table 1). The $\mathrm{Na}_{2} \mathrm{CO}_{3}$ stress treatments were included at ten concentrations $(10,20,25,30,40,50,75,100,125$, and $150 \mathrm{mM})$ to study the effects of alkaline and neutral salt stress on seed germination and seedling growth. The electrical conductivity and pH of all salt solutions were shown in Table 1.

TABLE 1 | pH and electrical conductivity (EC) of $\mathrm{NaCl}, \mathrm{NaHCO}_{3}$, and $\mathrm{Na}_{2} \mathrm{CO}_{3}$ solution at the various concentrations.

\begin{tabular}{|c|c|c|c|c|}
\hline \multirow[t]{2}{*}{ Treatment } & \multicolumn{2}{|c|}{ Concentration } & \multirow[t]{2}{*}{$\mathrm{pH}$} & \multirow{2}{*}{$\frac{E C}{\left(\mathrm{mS} \mathrm{cm}^{-1}\right)}$} \\
\hline & $\mathrm{mmol} \mathrm{L}^{-1}$ & $\%(w / v)$ & & \\
\hline Control & 0 & 0 & 6.05 & 0 \\
\hline \multirow[t]{6}{*}{$\mathrm{NaCl}$} & 50 & 0.29 & 6.10 & 4.84 \\
\hline & 100 & 0.59 & 5.91 & 9.24 \\
\hline & 150 & 0.88 & 5.72 & 13.63 \\
\hline & 200 & 1.18 & 5.70 & 18.21 \\
\hline & 250 & 1.47 & 5.68 & - \\
\hline & 300 & 1.77 & 5.62 & - \\
\hline \multirow[t]{6}{*}{$\mathrm{NaHCO}_{3}$} & 50 & 0.42 & 8.57 & 3.92 \\
\hline & 100 & 0.84 & 8.51 & 7.16 \\
\hline & 150 & 1.26 & 8.46 & 10.28 \\
\hline & 200 & 1.68 & 8.37 & 13.21 \\
\hline & 250 & 2.10 & 8.34 & 15.76 \\
\hline & 300 & 2.52 & 8.34 & - \\
\hline \multirow[t]{10}{*}{$\mathrm{Na}_{2} \mathrm{CO}_{3}$} & 10 & 0.11 & 10.89 & 2.04 \\
\hline & 20 & 0.21 & 10.99 & 3.73 \\
\hline & 25 & 0.27 & 11.05 & 4.51 \\
\hline & 30 & 0.32 & 11.05 & 5.26 \\
\hline & 40 & 0.43 & 11.12 & 6.76 \\
\hline & 50 & 0.53 & 11.15 & 8.12 \\
\hline & 75 & 0.80 & 11.18 & 11.53 \\
\hline & 100 & 1.06 & 11.22 & 14.69 \\
\hline & 125 & 1.33 & 11.20 & 17.64 \\
\hline & 150 & 1.60 & 11.19 & - \\
\hline
\end{tabular}

"-" indicates that the value exceeded the maximum measurement range. 
Another experiment was undertaken, with five $\mathrm{pH}$ levels (7.1, 8.0, 9.0, 10.0, and 11.0) and four $\mathrm{NaCl}$ levels (0, 100, 150, and $200 \mathrm{mM}$ ) to investigate the involvement of $\mathrm{pH}$ under salt and alkali stress on germination and seedling growth. Various $\mathrm{pH}$ buffer solutions were used to prepare the $\mathrm{NaCl}$ solution at different concentrations (Table 2).

\section{Germination Test}

Canola seeds of uniform size and roundness were sterilized in $0.5 \% \mathrm{NaClO}$ for $10 \mathrm{~min}$, then rinsed with sterilized Milli$Q$ water for five times. In each plastic germination box $(10 \mathrm{~cm} \times 10 \mathrm{~cm} \times 5 \mathrm{~cm}), 30$ seeds were spaced evenly on top of six layers of sterilized filter paper before adding $10 \mathrm{~mL}$ of sterilized saline solution. Each box was then covered with a lid and sealed with a sealing film. No further solution was added for the duration of the experiment. Experiment I included individual neutral salt and alkaline salt stress treatments (see Table 1), and Experiment II combined different $\mathrm{pH}$ levels for each $\mathrm{NaCl}$ treatment (see Table 2). There were three replicates per treatment, giving a total of 69 boxes in Experiment I and 60 boxes in Experiment II. The germination test was undertaken for 7 days in an artificial climate incubator set at $25^{\circ} \mathrm{C} / 20^{\circ} \mathrm{C}$ (day/night), with relative humidity of $50-55 \%$ and daily photosynthetic photon flux density of $300 \mu \mathrm{mol}$ photons $\mathrm{m}^{-2} \mathrm{~s}^{-1}$. The number of germinated seeds (when germ length reached seed length) was recorded daily. The germination energy was the germination rate recorded on the third day. After 7 days of germination, 10 seedlings with representative growth were randomly selected from each box to determine shoot length, root length, shoot fresh weight, and fresh root weight.

\section{Hydroponics Experiment}

Based on the germination tests under salt-alkali stress, the suitable saline-alkali species $\left(\mathrm{NaCl}\right.$ and $\left.\mathrm{Na}_{2} \mathrm{CO}_{3}\right)$ and concentration $(100,150$, and $200 \mathrm{mM} \mathrm{NaCl}$ and 20,30, and $40 \mathrm{Na}_{2} \mathrm{CO}_{3}$ ) were selected for a hydroponics experiment (Experiment II). For germination, one seed was sown in each hole in plastic germinating trays ( 72 holes per tray) containing vermiculite in an artificial climate chamber with temperature set at $25^{\circ} \mathrm{C}$ and $14 \mathrm{~h}$ photoperiod. After 7 days, six seedlings in uniform size were randomly selected from the germination tray, and then transplanted into a pot (upper diameter $13.5 \mathrm{~cm}$, bottom diameter $10.5 \mathrm{~cm}$, and height $12.5 \mathrm{~cm}$ ) filled with vermiculite and watered with $100 \mathrm{~mL}$ of 1/4 strength Hoagland nutrient solution every 2 days. Thirty-five days after growing in vermiculite when the seedlings had three true leaves, the seedlings were transferred to hydroponics with 1/4 strength Hoagland solution (Hothem et al., 2003) that was replaced every second day. Hoagland's solution contained $\left(\mathrm{mg} \mathrm{l} \mathrm{l}^{-1}\right)$ : $\mathrm{MgSO}_{4} \cdot 7 \mathrm{H}_{2} \mathrm{O}$ 493; $\mathrm{Ca}\left(\mathrm{NO}_{3}\right)_{2} \cdot 4 \mathrm{H}_{2} \mathrm{O} 1180 ; \mathrm{KH}_{2} \mathrm{PO}_{4} 136 ; \mathrm{KNO}_{3}$ 505; $\mathrm{H}_{3} \mathrm{BO}_{3}$ 2.86; $\mathrm{MnCl}_{2} \cdot 4 \mathrm{H}_{2} \mathrm{O} 1.82 ; \mathrm{ZnSO}_{4} \cdot 7 \mathrm{H}_{2} \mathrm{O} 0.22 ; \mathrm{CuSO}_{4} \cdot 5 \mathrm{H}_{2} \mathrm{O} 0.09$; $\mathrm{MoO}_{3}$ 0.01; Fe-DTPA 50; and had a pH of 6.5. After 14 days in hydroponics, when the seedlings had five true leaves, the nutrient solution was changed to $1 / 2$ strength. Three days later, the following treatments were implemented: control (1/2 strength Hoagland nutrient solution), neutral stress treatments at $100 \mathrm{mM}$ (low), $150 \mathrm{mM}$ (moderate), and $200 \mathrm{mM}$ (high) $\mathrm{NaCl}$, and alkali

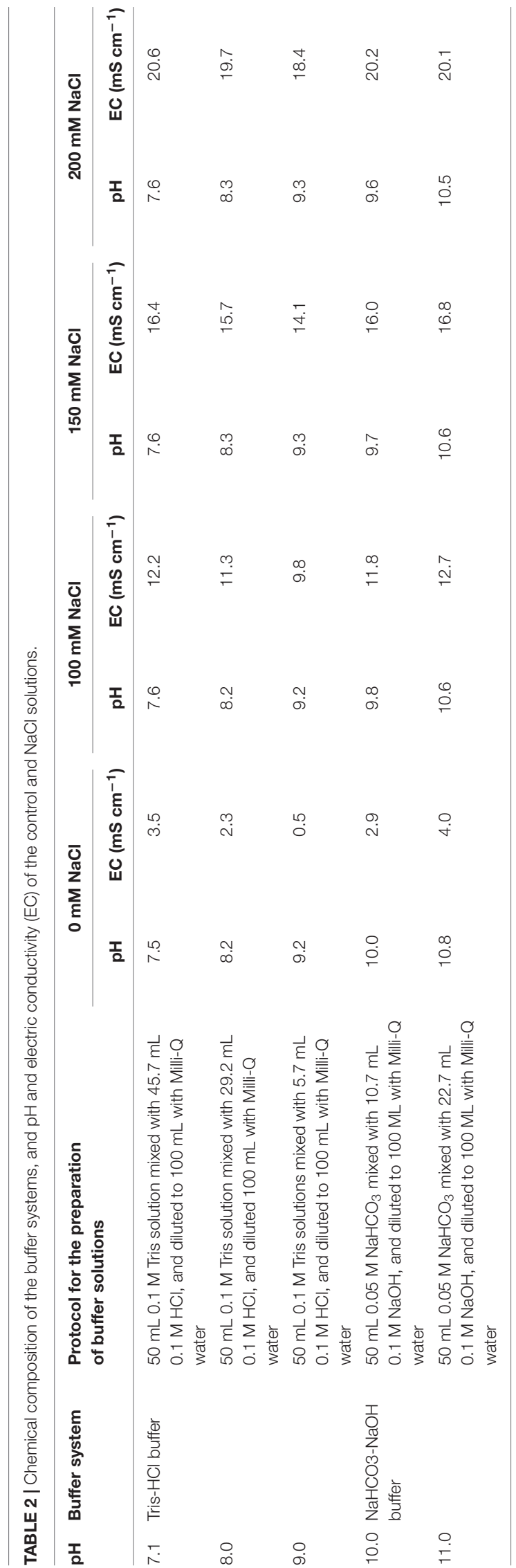


stress treatments with at $20 \mathrm{mM}$ (low), $30 \mathrm{mM}$ (moderate), and $40 \mathrm{mM}$ (high) $\mathrm{Na}_{2} \mathrm{CO}_{3}$. After 3 days, the seedlings, especially the roots, were washed in Milli-Q water to remove the residual vermiculite in the roots, and the roots, stems, and leaves were separated and harvested.

\section{Determination of $\mathrm{Na}^{+}, \mathrm{K}^{+}, \mathrm{Ca}^{2+}, \mathrm{Mg}^{2+}$, $\mathrm{Cl}^{-}$, and $\mathrm{SO}_{4}{ }^{2-}$ Concentrations}

Root, stem, and leaf samples from the hydroponic experiment were oven-dried at $105^{\circ} \mathrm{C}$ for $30 \mathrm{~min}$ and then $80^{\circ} \mathrm{C}$ for $48 \mathrm{~h}$. Approximately, $0.01 \mathrm{~g}$ of dried plant samples were pulverized in a crucible and then combusted in a muffle furnace (Carbolite CWF Laboratory Chamber Furnaces, CARBOLITE CWF 1300, England) for $8 \mathrm{~h}$ at $550^{\circ} \mathrm{C}$. After cooling to room temperature, $10 \mathrm{~mL}$ of Milli-Q water was added to each crucible to dissolve the ash. After stirring, the solution was transferred to a $100 \mathrm{~mL}$ volumetric flask, and Milli-Q water was added to volume. The samples were analyzed to determine $\mathrm{Na}^{+}, \mathrm{K}^{+}, \mathrm{Ca}^{2+}, \mathrm{Mg}^{2+}, \mathrm{Cl}^{-}$, and $\mathrm{SO}_{4}{ }^{2-}$ concentrations using ion chromatography (Thermo SCIENTIFIC Ion Chromatography System DIONEX ICS-1100, Waltham, MA, United States; Cation Exchange Column: Thermo Dionex $^{\text {TM }}$ IonPac $^{\text {TM }}$ CS12A $4 \mathrm{~mm} \times 250 \mathrm{~mm}$ and CG12A $4 \mathrm{~mm} \times 50 \mathrm{~mm}$; Anion Exchange Column: Thermo Dionex ${ }^{\mathrm{TM}}$ IonPac $^{\text {TM }}$ AS19 $4 \mathrm{~mm} \times 250 \mathrm{~mm}$ and AS19 $4 \mathrm{~mm} \times 50 \mathrm{~mm}$ ).

\section{Statistics}

The data were subjected to one- or two-way analysis of variance (ANOVA), and the least significant difference (LSD) test at $P=0.05$ was used to determine differences among treatments using the SPSS 20.0 statistics package (SPSS, Chicago, IL, United States). The data in the Tables and Figures are expressed as mean \pm standard error $(n=3)$.

\section{RESULTS}

\section{Seed Germination Rate and Seedling Growth Index}

The germination percentage was $>90 \%$ from $0 \mathrm{mM}$ to $200 \mathrm{mM}$ $\mathrm{NaCl}$ (Figure 1), declining to $60 \%$ at $250 \mathrm{mM} \mathrm{NaCl}$ and almost $0 \%$ at $300 \mathrm{mM}$. The germination percentage was $90 \%$ at $50 \mathrm{mM}$ $\mathrm{NaHCO}_{3}$, declining to $23 \%$ at $100 \mathrm{mM}, 7 \%$ at $150 \mathrm{mM}$, and $1 \%$ at $200 \mathrm{mM} \mathrm{NaHCO} 3$. At $10-30 \mathrm{mM} \mathrm{Na}_{2} \mathrm{CO}_{3}$, the germination percentage was $>70 \%$, declining to $29 \%$ at $50 \mathrm{mM}, 7 \%$ at $100 \mathrm{mM}$, and almost $0 \%$ at $125-150 \mathrm{mM} \mathrm{Na}_{2} \mathrm{CO}_{3}$.

Compared with the control, shoot length and shoot fresh weight increased by $28 \%$ and $37 \%$ at $50 \mathrm{mM} \mathrm{NaCl}$, did not significantly differ at $100 \mathrm{mM}$ and $150 \mathrm{mM} \mathrm{NaCl}$, and declined by $58 \%$ and $35 \%$ at $200 \mathrm{mM} \mathrm{NaCl}$ and $62 \%$ and $51 \%$ at $250 \mathrm{mM}$ $\mathrm{NaCl}$, respectively (Figures 2A,D). $\mathrm{NaCl}$ stress significantly decreased root length compared to the control, by 39-90\% from $50 \mathrm{mM}$ to $250 \mathrm{mM} \mathrm{NaCl}$. Compared with the control, root fresh weight increased by $17 \%$ and $13 \%$ at 50 and $100 \mathrm{mM} \mathrm{NaCl}$, respectively, and decreased by 17,48 , and $61 \%$ at 150,200 , and $250 \mathrm{mM} \mathrm{NaCl}$, respectively. At $50 \mathrm{mM} \mathrm{NaHCO}_{3}$, shoot length,

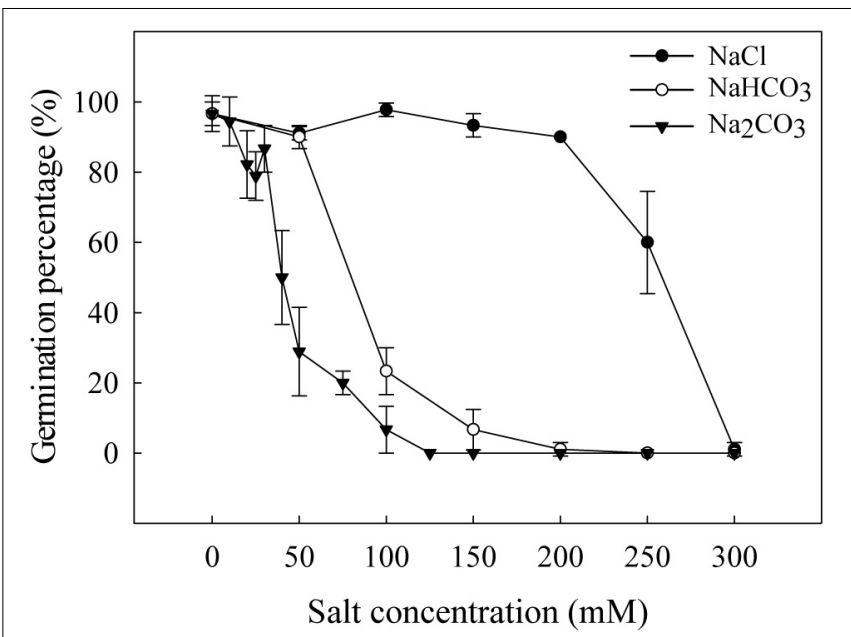

FIGURE 1 | Germination percentage of canola seeds under varying levels of saline-alkali stress.

root length, shoot fresh weight, and root fresh weight declined by $47,90,36$, and 62\%, respectively, than the control (Figures 2B,E).

Low $\mathrm{Na}_{2} \mathrm{CO}_{3}(10 \mathrm{mM})$ increased shoot length and shoot fresh weight by 40 and $36 \%$ compared with the control; higher $\mathrm{Na}_{2} \mathrm{CO}_{3}$ concentrations decreased shoot length and shoot fresh weight. At $\geq 25 \mathrm{mM} \mathrm{Na} \mathrm{CO}_{3}$, shoot length and shoot fresh weight decreased relative to the control (Figures 2C,F). At 10, 20, 25 , 30, and $40 \mathrm{mM} \mathrm{Na} \mathrm{CO}_{3}$, root length decreased by $51-96 \%$, relative to the control.

Under the same $\mathrm{Na}^{+}$concentration, the alkaline salts $\left(\mathrm{Na}_{2} \mathrm{CO}_{3}, \mathrm{NaHCO}_{3}\right)$ had stronger inhibitory effects on seed germination and seedling growth than the neutral salt $(\mathrm{NaCl})$.

\section{Interactive Effect of pH and Salinity on Seed Germination and Seedling Growth of Canola}

The two-way ANOVA results showed that seed germination percentage and seedling growth were affected by $\mathrm{NaCl}, \mathrm{pH}$, and their interactions (Figures 3, 4). Germination percentage decreased with increasing salinity and alkalinity $(\mathrm{pH})$ (Figure 3). At $\mathrm{pH} 7.1$ and 8.0, the germination percentage of canola seeds at 100,150 , and $200 \mathrm{mM} \mathrm{NaCl}$ did not significantly differ from $0 \mathrm{mM} \mathrm{NaCl}$. At $\mathrm{pH} \mathrm{9,10,} \mathrm{and} \mathrm{11,} \mathrm{germination} \mathrm{percentage} \mathrm{at} 100$ and $150 \mathrm{mM} \mathrm{NaCl}$ did not significantly differ from $0 \mathrm{mM} \mathrm{NaCl}$, but decreased significantly at $200 \mathrm{mM} \mathrm{NaCl}$, with reductions of 24,48 , and $38 \%$ at $\mathrm{pH} 9.0,10.0$, and 11.0, respectively.

Shoot fresh weight (SFW, Figure 4A), shoot length (SL, Figure 4B), root fresh weight (RFW, Figure 4C), and root length (RL, Figure 4D) of canola seedlings decreased with increasing $\mathrm{NaCl}$ concentration at the same $\mathrm{pH}$. At $\mathrm{pH} \leq 9.0$, SFW at 100 and $150 \mathrm{mM} \mathrm{NaCl}$ did not significantly differ from $0 \mathrm{mM} \mathrm{NaCl}$, but at $200 \mathrm{mM} \mathrm{NaCl}$, SFW decreased by 49, 44, and 39\% at $\mathrm{pH} 7.1,8.0$, and 9.0, respectively (Figure 4A). At $\mathrm{pH} \geq 10.0$, SFW decreased by $29-61 \%$ with increasing salinity $(100-200 \mathrm{mM} \mathrm{NaCl})$, relative to $0 \mathrm{mM} \mathrm{NaCl}$. At pH 7.1, SL at 100 and $150 \mathrm{mM} \mathrm{NaCl}$ did not significantly differ from $0 \mathrm{mM} \mathrm{NaCl}$ (Figure 4B), but decreased 


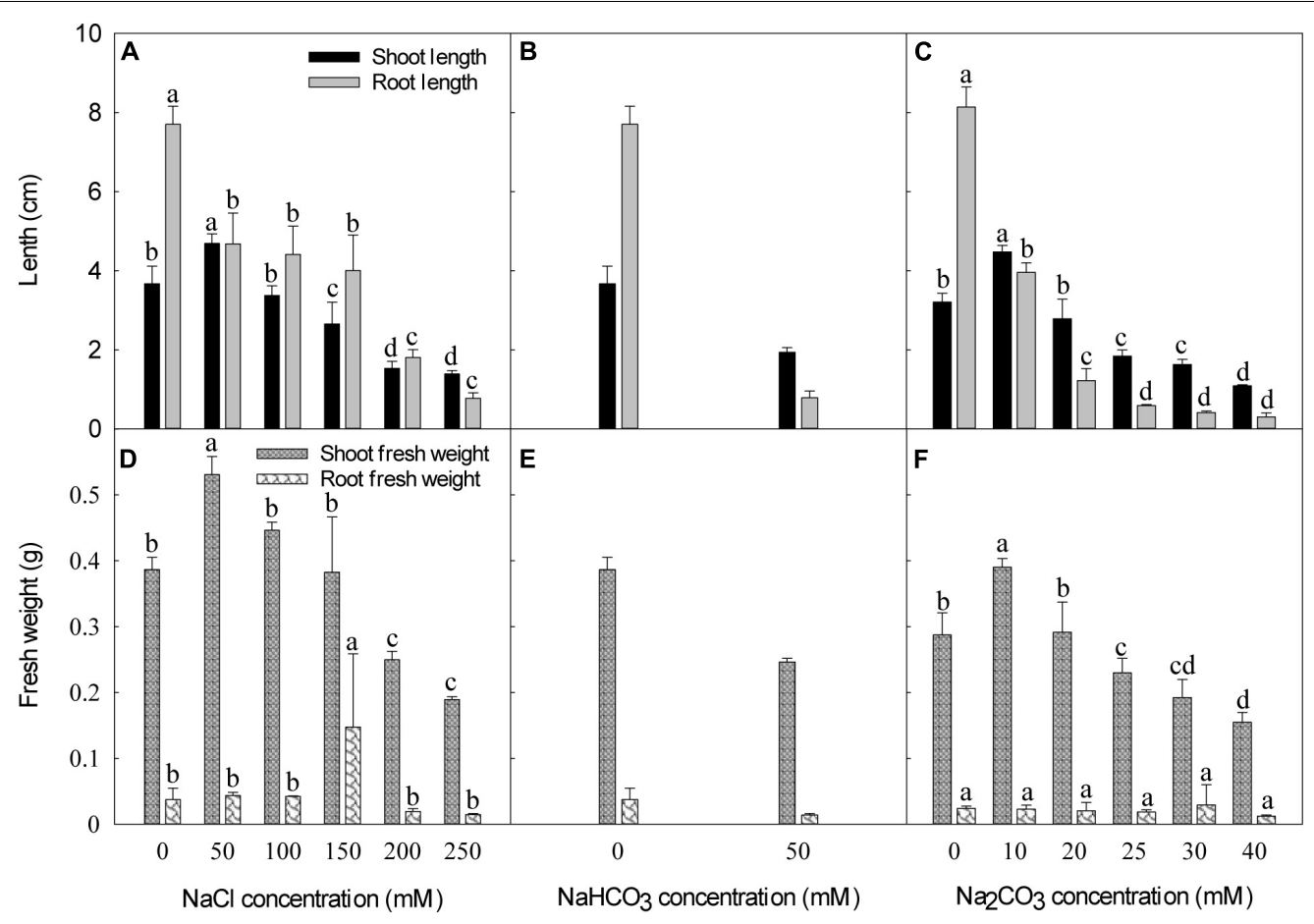

FIGURE 2 | Effect of different $\mathrm{NaCl}, \mathrm{NaHCO}_{3}$, and $\mathrm{Na}_{2} \mathrm{CO}_{3}$ concentrations on shoot and root length (A-C), and shoot and root fresh weight (D-F) of canola seedlings 7 days after germination. Different lowercase letters indicate the significant differences between salt concentrations within the same growth parameter, according to the least significant difference (LSD) test $(P<0.05)$.

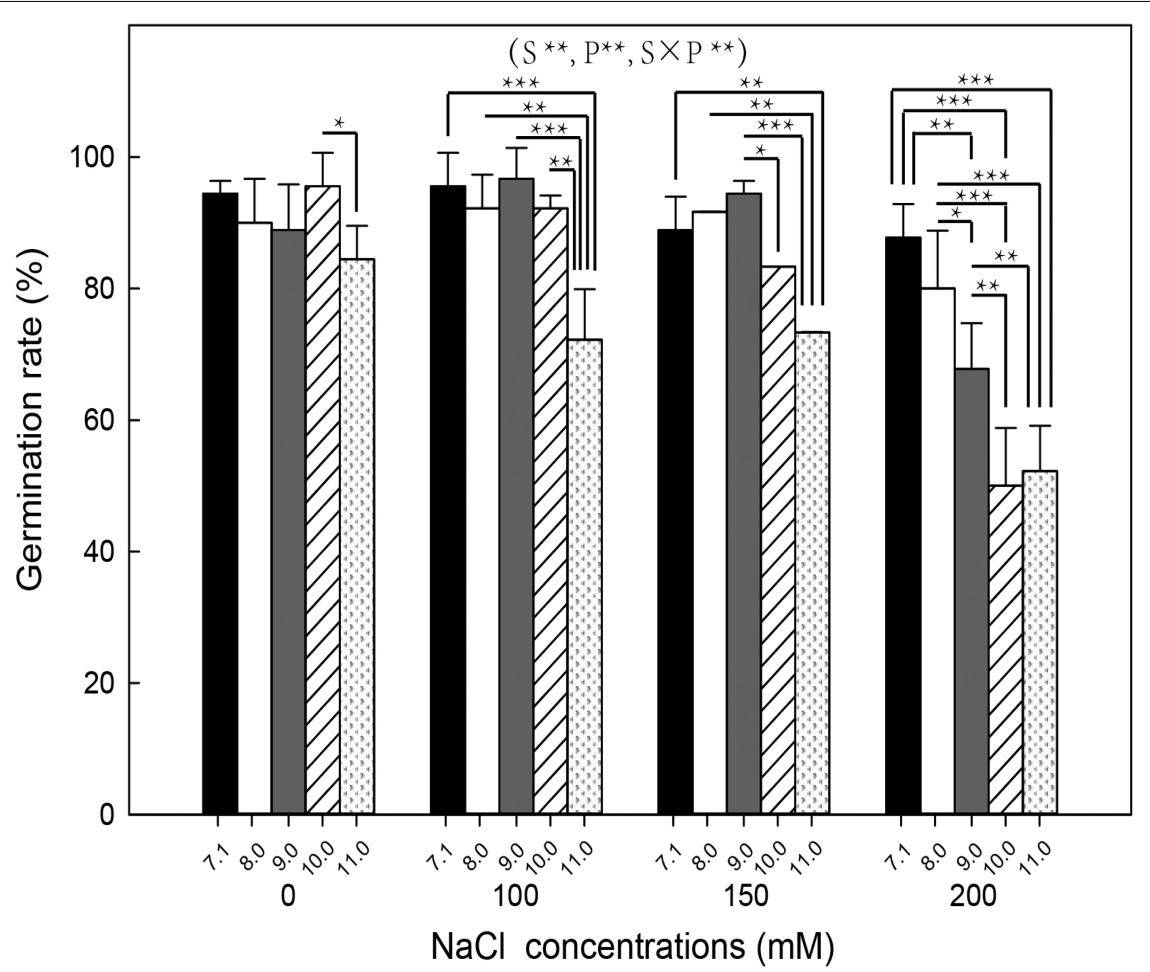

FIGURE 3 | Germination percentage of canola seeds (day 7) under combined $\mathrm{NaCl}(0,100,150$, and $200 \mathrm{mM})$ and pH level (7.1, 8.0, 9.0, 10.0, and 11.0). S is $\mathrm{NaCl}, \mathrm{P}$ is $\mathrm{pH}$, and $\mathrm{S} \times \mathrm{P}$ is their interaction, ${ }^{*},{ }^{* *}$, and ${ }^{* * *}$ indicate significance at $P=0.05,0.01$, and 0.001 , respectively, according to the least significant difference (LSD) test for simple effects analysis of two-way ANOVA interactions $(P<0.05)$. 

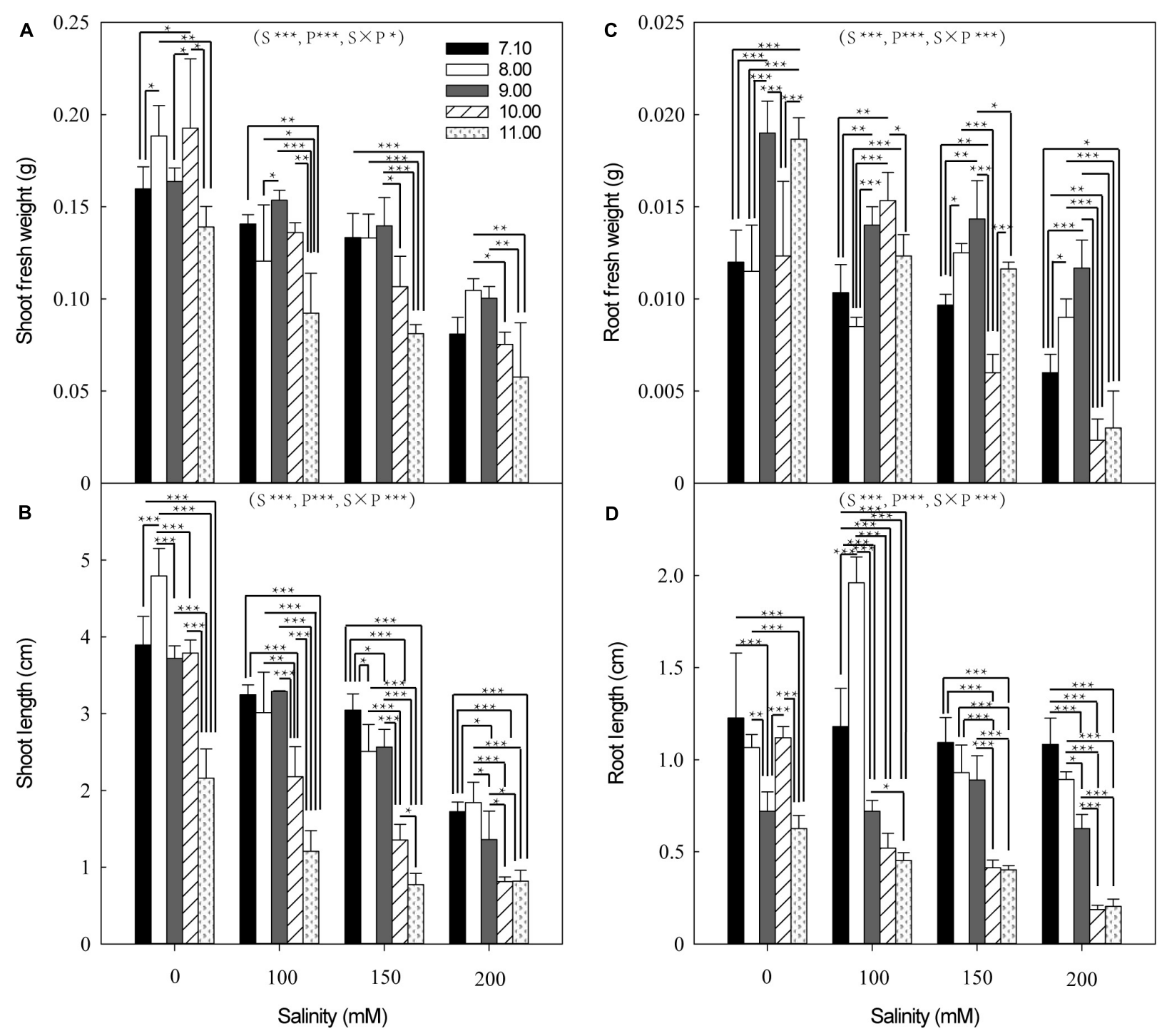

FIGURE 4 | Interactive effects of $\mathrm{NaCl}$ and $\mathrm{pH}$ on shoot fresh weight (A), root fresh weight (B), shoot length (C), and root length (D) of canola seedling 7 days of germination. $\mathrm{S}$ is salinity, $\mathrm{P}$ is $\mathrm{pH}$, and $\mathrm{S} \times \mathrm{P}$ is their interaction, ${ }^{*},{ }^{* *}$, and ${ }^{* * *}$ indicate significance at $P=0.05,0.01$, and 0.001, respectively, according to the least significant difference (LSD) test for simple effects analysis of two-way ANOVA interactions $(P<0.05)$.

by $56 \%$ at $200 \mathrm{mM} \mathrm{NaCl}$. At $\mathrm{pH} \geq 8.0$, SL decreased with increasing salinity (100-200 $\mathrm{mM} \mathrm{NaCl})$; more specifically, by $37-$ $62 \%$ at $\mathrm{pH} 8.0,12-63 \%$ at $\mathrm{pH} 9.0,42-79 \%$ at $\mathrm{pH} 10.0$, and $44-62 \%$ at $\mathrm{pH} 11.0$, compared with $0 \mathrm{mM} \mathrm{NaCl}$. At $\mathrm{pH} \leq 9.0$, RFW did not significantly differ between $\mathrm{NaCl}$ concentrations (Figure 4C). At pH 10.0, RFW increased at $100 \mathrm{mM} \mathrm{NaCl}$, but decreased by 51 and $81 \%$ at 150 and $200 \mathrm{mM} \mathrm{NaCl}$, respectively, compared with $0 \mathrm{mM} \mathrm{NaCl}$. At pH 11.0, RFW decreased by 34, 38, and $84 \%$ at 100,150 , and $200 \mathrm{mM} \mathrm{NaCl}$, respectively, compared with $0 \mathrm{mM}$ $\mathrm{NaCl}$. At $\mathrm{pH} \leq 9.0$, RL did not significantly differ between $\mathrm{NaCl}$ concentrations, except for $\mathrm{pH} 8.0$ at $100 \mathrm{mM} \mathrm{NaCl}$ when it was greater than $0 \mathrm{mM} \mathrm{NaCl}$ (Figure 4D). At $\mathrm{pH} \geq 10.0$, RL decreased with increasing salinity, by 54,63 , and $83 \%$ at $\mathrm{pH} 10.0$ and 28,36 , and $68 \%$ at $\mathrm{pH} 11.0$ at 100,150 , and $200 \mathrm{mM} \mathrm{NaCl}$, respectively, compared with $0 \mathrm{mM} \mathrm{NaCl}$.

\section{Ion Changes in Canola Seedlings Under Saline-Alkali Stress \\ $\mathrm{Na}^{+}$Concentration}

Leaf $\left[\mathrm{Na}^{+}\right]$significantly increased when $\mathrm{NaCl}$ increased from 0 to $100 \mathrm{mM}(696 \%)$ and $150 \mathrm{mM}(650 \%)$, followed by a slight but significant decrease at $200 \mathrm{mM}(599 \%)(P<0.05)$, compared with $0 \mathrm{mM} \mathrm{NaCl}$ (Figure 5A). Leaf $\left[\mathrm{Na}^{+}\right]$increased by 41, 100, and $104 \%$ at 20,30 , and $40 \mathrm{mM} \mathrm{Na}_{2} \mathrm{CO}_{3}$, respectively, compared with $0 \mathrm{mM} \mathrm{Na} \mathrm{CO}_{3}$ (Figure 5A). Stem $\left[\mathrm{Na}^{+}\right]$increased by 261, 111, and $261 \%$ at 100,150 , and $200 \mathrm{mM} \mathrm{NaCl}$ and 136,77 , and $103 \%$ at 20,30 , and $40 \mathrm{mM} \mathrm{Na}_{2} \mathrm{CO}_{3}$, respectively, compared with control (Figure 5B). Root $\left[\mathrm{Na}^{+}\right]$remained relatively constant at 0,100 , and $150 \mathrm{mM} \mathrm{NaCl}$, but significantly increased at $200 \mathrm{mM} \mathrm{NaCl}$ (Figure 5C). Root $\left[\mathrm{Na}^{+}\right]$at all $\mathrm{Na}_{2} \mathrm{CO}_{3}$ concentrations did not 


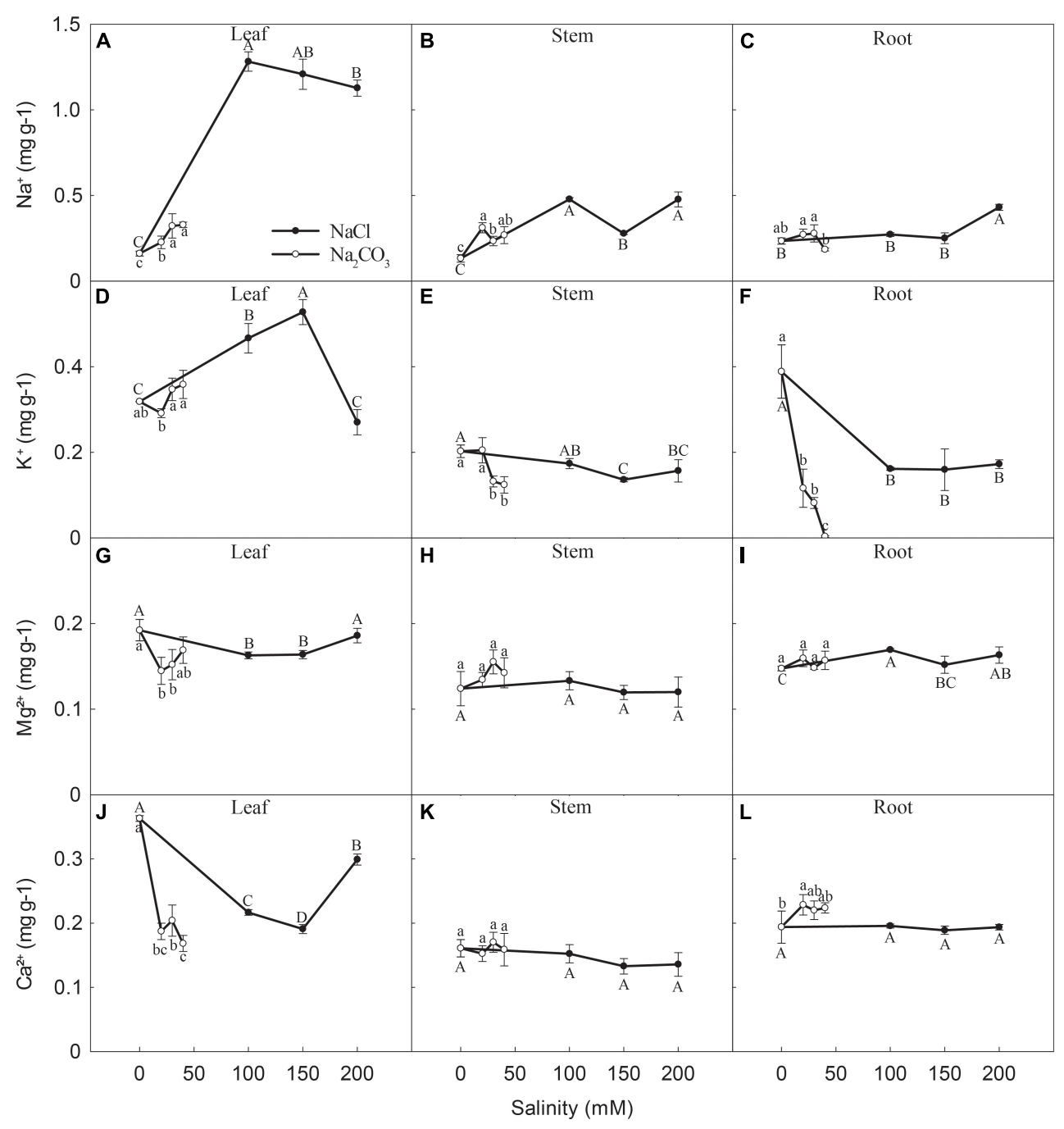

FIGURE 5 | Changes in the concentrations of (A-C) $\left.\mathrm{Na}^{+}, \mathbf{( D - F}\right) \mathrm{K}^{+},(\mathbf{G}-\mathbf{I}) \mathbf{M g}^{2+}$, and $\left.\mathbf{( J - L}\right) \mathrm{Ca}^{2+}$ in the leaves, stems, and roots of canola seedlings after 7 days of $\mathrm{NaCl}$ and $\mathrm{Na}_{2} \mathrm{CO}_{3}$ stress. Different uppercase and lowercase letters indicate significant differences among $\mathrm{NaCl} \mathrm{and} \mathrm{Na}_{2} \mathrm{CO}_{3} \mathrm{Concentrations}$ respectively, according to a least significant difference (LSD) test $(P<0.05)$.

significantly differ from the control but was significantly lower at $40 \mathrm{mM}$ than at $20 \mathrm{mM}$ and $30 \mathrm{mM}$ (Figure 5C).

\section{$\mathrm{K}^{+}$Concentration}

Leaf $\left[\mathrm{K}^{+}\right]$significantly increased at 100 and $150 \mathrm{mM} \mathrm{NaCl}$, relative to the control, but significantly decreased to close to the control at $200 \mathrm{mM} \mathrm{NaCl}$ (Figure 5D). Leaf $\left[\mathrm{K}^{+}\right]$in the $\mathrm{Na}_{2} \mathrm{CO}_{3}$ treatments did not significantly differ from the control but was significantly higher at 30 and $40 \mathrm{mM} \mathrm{Na}_{2} \mathrm{CO}_{3}$ than at $20 \mathrm{mM} \mathrm{Na}_{2} \mathrm{CO}_{3}$ (Figure 5D). Stem $\left[\mathrm{K}^{+}\right]$significantly decreased at 150 and $200 \mathrm{mM} \mathrm{NaCl}$ and 30 and $40 \mathrm{mM} \mathrm{Na}_{2} \mathrm{CO}_{3}$ relative to the control (Figure 5E). Root $\left[\mathrm{K}^{+}\right]$increased by 58, 59, and $56 \%$ at 100,150 , and $200 \mathrm{mM} \mathrm{NaCl}$, respectively, compared to the control, with no significant differences between the three $\mathrm{NaCl}$ concentrations (Figure 5F). Root $\left[\mathrm{K}^{+}\right]$decreased by 70 , 79 , and $99 \%$ at 20,30 , and $40 \mathrm{mM} \mathrm{Na}_{2} \mathrm{CO}_{3}$ stress, respectively relative to the control.

\section{$\mathrm{Mg}^{2+}$ Concentration}

Leaf $\left[\mathrm{Mg}^{2+}\right]$ significantly declined at 100 and $150 \mathrm{mM} \mathrm{NaCl}$, relative to the control, but increased to a similar value to the control at $200 \mathrm{mM} \mathrm{NaCl}$ (Figure 5G). Leaf $\left[\mathrm{Mg}^{2+}\right]$ significantly decreased at 20 and $30 \mathrm{mM} \mathrm{Na}_{2} \mathrm{CO}_{3}$, relative to the control, but did not significantly differ between 20, 30, and $40 \mathrm{mM} \mathrm{Na} \mathrm{CO}_{3}$ (Figure 5G). Stem $\left[\mathrm{Mg}^{2+}\right]$ did not significantly differ among different concentrations when treated with either $\mathrm{NaCl}$ or $\mathrm{Na}_{2} \mathrm{CO}_{3}$ (Figure 5H). Root $\left[\mathrm{Mg}^{2+}\right]$ at 100 and $200 \mathrm{mM} \mathrm{NaCl}$ increased slightly $(P<0.05)$, compared with the control, but did not significantly differ between $\mathrm{Na}_{2} \mathrm{CO}_{3}$ concentrations (Figure 5I).

\section{$\mathrm{Ca}^{2+}$ Concentration}

Leaf $\left[\mathrm{Ca}^{2+}\right]$ decreased significantly at 20,30, and $40 \mathrm{mM}$ $\mathrm{Na}_{2} \mathrm{CO}_{3}$, relative to the control (Figure 5J). Leaf $\left[\mathrm{Ca}^{2+}\right]$ also 


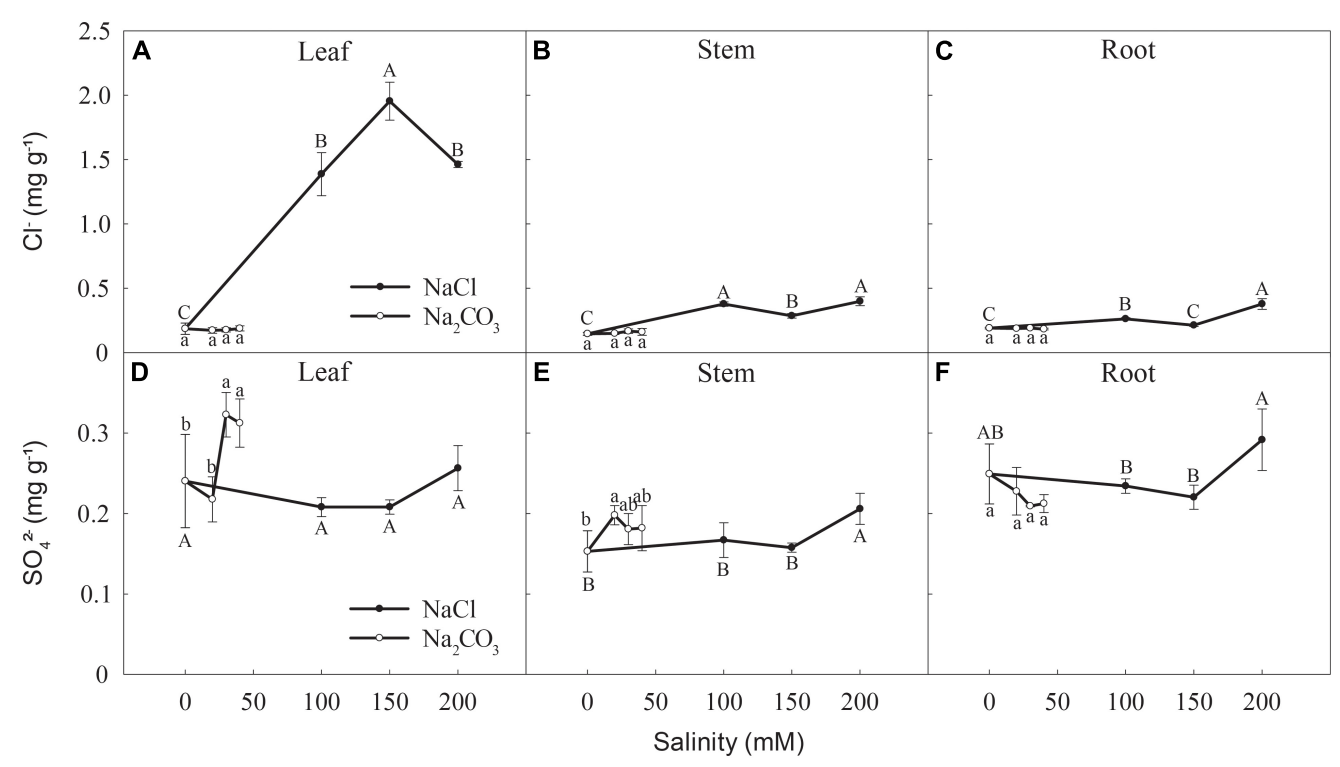

FIGURE 6 | Changes in the concentrations of (A-C) $\mathrm{Cl}^{-}$and (D-F) $\mathrm{SO}_{4}{ }^{2-}$ in the leaves, stems, and roots of canola seedlings after 7 days of $\mathrm{NaCl}$ and $\mathrm{Na}_{2} \mathrm{CO}_{3}$ stress. Different uppercase and lowercase letters indicate significant difference among $\mathrm{NaCl}$ and $\mathrm{Na}_{2} \mathrm{CO}_{3}$ concentrations, respectively, according to a least significant difference (LSD) test $(P<0.05)$.

decreased significantly at 100 and $150 \mathrm{mM} \mathrm{NaCl}$, compared with the control, but increased sharply at $200 \mathrm{mM}$ (Figure 5J). Similar to stem $\left[\mathrm{Mg}^{2+}\right]$, stem $\left[\mathrm{Ca}^{2+}\right]$ varied little when treated with $\mathrm{NaCl}$ or $\mathrm{Na}_{2} \mathrm{CO}_{3}$ (Figure $5 \mathrm{~K}$ ). Root $\left[\mathrm{Ca}^{2+}\right]$ increased significantly at 20, 30, and $40 \mathrm{mM} \mathrm{Na} 2 \mathrm{CO}_{3}$, relative to the control, while $\mathrm{NaCl}$ had little effect on root $\left[\mathrm{Ca}^{2+}\right]$ (Figure 5L).

\section{$\mathrm{Cl}^{-}$Concentration}

$\mathrm{NaCl}$ significantly increased $\left[\mathrm{Cl}^{-}\right]$in leaves (Figure 6A), stems (Figure 6B), and roots (Figure 6C), relative to the control. Leaf $\left[\mathrm{Cl}^{-}\right]$had similar values at 100 and $200 \mathrm{mM} \mathrm{NaCl}$, and the highest value at $150 \mathrm{mM}$. Stem $\left[\mathrm{Cl}^{-}\right]$was highest at 100 and $200 \mathrm{mM}$ $\mathrm{NaCl}$, followed by $150 \mathrm{mM}$. Root $\left[\mathrm{Cl}^{-}\right]$had the highest value at $200 \mathrm{mM}$, followed by $100 \mathrm{mM}$, with no significant difference between $150 \mathrm{mM}$ and the control (Figure 6C). The $\mathrm{Na}_{2} \mathrm{CO}_{3}$ treatments had little effect on $\left[\mathrm{Cl}^{-}\right]$in leaves, stems, or roots (Figures 6A-C).

\section{$\mathrm{SO}_{4}{ }^{2-}$ Concentration}

Leaf $\left[\mathrm{SO}_{4}{ }^{2-}\right]$ at 30 and $40 \mathrm{mM} \mathrm{Na} \mathrm{CO}_{3}$ significantly increased relative to the control and $20 \mathrm{mM} \mathrm{Na}_{2} \mathrm{CO}_{3}$, but there were no significant effects of the $\mathrm{NaCl}$ treatments (Figure 6D). Stem $\left[\mathrm{SO}_{4}{ }^{2-}\right]$ significantly increased at $20 \mathrm{mM} \mathrm{Na}_{2} \mathrm{CO}_{3}$, relative to the control, but did not significantly differ at 30 and $40 \mathrm{mM} \mathrm{Na}_{2} \mathrm{CO}_{3}$ (Figure 6E). Stem and root $\left[\mathrm{SO}_{4}{ }^{2-}\right]$ at $200 \mathrm{mM} \mathrm{NaCl}$ significantly increased relative to the control but did not significantly differ at $100 \mathrm{mM}$ and $150 \mathrm{mM} \mathrm{NaCl}$ (Figures 6E,F). The $\mathrm{Na}_{2} \mathrm{CO}_{3}$ treatments did not affect root $\left[\mathrm{SO}_{4}{ }^{2-}\right]$ (Figure 6F).

$\mathrm{K}^{+} / \mathrm{Na}^{+}, \mathrm{Ca}^{2+} / \mathrm{Na}^{+}$, and $\mathrm{Mg}^{2+} / \mathrm{Na}^{+}$Ratios in Different Tissues

The $\mathrm{K}^{+} / \mathrm{Na}^{+}$ratio in roots, stems, and leaves of canola seedlings decreased significantly with increasing $\mathrm{Na}_{2} \mathrm{CO}_{3}$ concentration, relative to the control (Table 3 ). Among the different tissues, the $\mathrm{K}^{+} / \mathrm{Na}^{+}$ratio under $\mathrm{Na}_{2} \mathrm{CO}_{3}$ followed the order of leaves $>$ stems $>$ roots $(P<0.05)$. The $\mathrm{K}^{+} / \mathrm{Na}^{+}$ratio decreased significantly with increasing $\mathrm{NaCl}$ concentration, compared with the control; and it was higher in the roots than that in the leaves and stems $(P<0.05)$.

Both $\mathrm{NaCl}$ and $\mathrm{Na}_{2} \mathrm{CO}_{3}$ stress significantly decreased the $\mathrm{Ca}^{2+} / \mathrm{Na}^{+}$and $\mathrm{Mg}^{2+} / \mathrm{Na}^{+}$ratios in stems and leaves; however, those ratios in the roots at 100 and $150 \mathrm{mM} \mathrm{NaCl}$ and 20 and $30 \mathrm{mM} \mathrm{Na} \mathrm{CO}_{3}$ were similar to the control. Root $\mathrm{Ca}^{2+} / \mathrm{Na}^{+}$ and $\mathrm{Mg}^{2+} / \mathrm{Na}^{+}$ratios at $200 \mathrm{mM} \mathrm{NaCl}$ significantly decreased relative to the controls, but they significantly increased at $40 \mathrm{mM} \mathrm{Na} \mathrm{CO}_{3}$. Roots had significantly higher $\mathrm{Ca}^{2+} / \mathrm{Na}^{+}$ and $\mathrm{Mg}^{2+} / \mathrm{Na}^{+}$ratios than stems and leaves in the same $\mathrm{NaCl}$ treatment. The $\mathrm{Ca}^{2+} / \mathrm{Na}^{+}$and $\mathrm{Mg}^{2+} / \mathrm{Na}^{+}$ratios did not significantly differ between roots and leaves at 20 and $30 \mathrm{mM}$, but were higher in roots than stems and leaves at $40 \mathrm{mM}$.

\section{DISCUSSION}

\section{Comparison of Different Types of Saline-Alkali Stress on Seed Germination and Seedling Growth}

Low salinity (50 mM NaCl and $10 \mathrm{mM} \mathrm{Na}_{2} \mathrm{CO}_{3}$ ) promoted shoot growth of canola seedlings, but high salt stress significantly inhibited seed germination (Figure 1) and plant root growth (Figure 2). At the same $\mathrm{Na}^{+}$concentration, alkaline salt stress $\left(\mathrm{Na}_{2} \mathrm{CO}_{3}\right.$ or $\left.\mathrm{NaHCO}_{3}\right)$ inhibited seed germination and seedling growth more than neutral salt stress $(\mathrm{NaCl})$, which may be due to a $\mathrm{pH}$ effect for alkaline salt in addition to the ion factor caused by neutral stress (Wang et al., 2011, 2017). At the same $\mathrm{Na}^{+}$ 


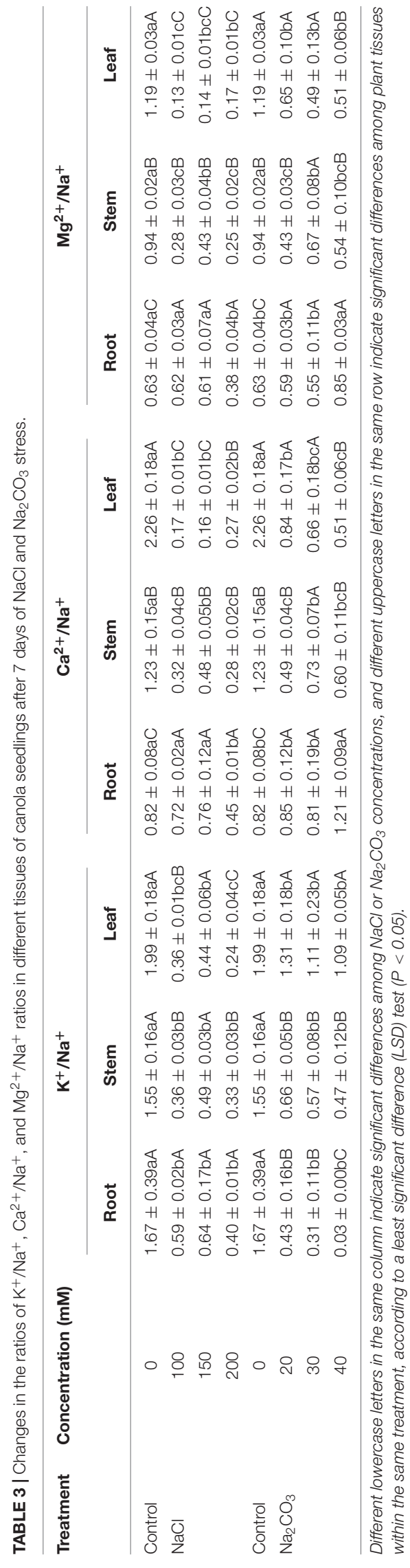

concentration, $\mathrm{Na}_{2} \mathrm{CO}_{3}$ had higher $\mathrm{pH}$ and EC than $\mathrm{NaHCO}_{3}$, but the germination percentage was higher under $\mathrm{Na}_{2} \mathrm{CO}_{3}$ than under $\mathrm{NaHCO}_{3}$, suggesting that factors other than $\mathrm{pH}$ (e.g., ion type and ion concentration) affect germination and seedling growth in canola.

\section{Interactive Effects of pH and Salinity on Seed Germination and Seedling Growth}

Salinity, $\mathrm{pH}$, and their interaction significantly affected seed germination and seedling growth of canola. At $100 \mathrm{mM} \mathrm{NaCl}$, the germination rate reduced significantly at high $\mathrm{pH}(\geq 11.00)$, while at $200 \mathrm{mM} \mathrm{NaCl}$, the germination rate was significantly reduced at $\mathrm{pH} \geq 9.0$, these results demonstrate the interaction of pH and salinity. However, Zhao et al. (2014) have reported that non-significant interactions between $\mathrm{Na}^{+}$concentration and $\mathrm{pH}$ on germination rate. Some studies have also shown significantly higher interactive effects of salinity and high $\mathrm{pH}$ on plants than salinity or $\mathrm{pH}$ alone (Li et al., 2010; Hu et al., 2018; Lin et al., 2018), but this was demonstrated more in this study by introducing a $\mathrm{pH}$ buffer system that excluded other factors. High $\mathrm{pH}$ reduced the average germination time and increased the germination rate of sorghum even under low $\mathrm{Na}^{+}$concentration (Zhao et al., 2014). Compared with the individual alkali stress $\left(\mathrm{Na}_{2} \mathrm{CO}_{3}\right)$, canola seedlings treated with $100 \mathrm{mM} \mathrm{NaCl}$ at $\mathrm{pH} 11.0$ had a much higher germination percentage than those treated with $50 \mathrm{mM} \mathrm{Na}_{2} \mathrm{CO}_{3}$ at $\mathrm{pH} 11.15$, despite both treatments having the same $\mathrm{Na}^{+}$concentration and $\mathrm{pH}$ value. These results suggest that species of cations and anions affect canola germination and growth, in addition to $\mathrm{pH}$ and salt concentration.

\section{Ion Accumulation}

Under saline-alkali stress, plants can enhance selective ion absorption by roots and regulate their distribution within the plant to achieve a stable ion status, as an underlying mechanism of salinity tolerance (Ben-Amor et al., 2010; Golldack et al., 2014; Cao et al., 2020). We showed that root, stem, and leaf $\mathrm{Na}^{+}$ concentrations in canola seedlings increased under $\mathrm{NaCl}$ and $\mathrm{Na}_{2} \mathrm{CO}_{3}$ stress while root and stem $\mathrm{K}^{+}$concentrations decreased due to competition between $\mathrm{Na}^{+}$and $\mathrm{K}^{+}$absorption. Studies have shown that salinity reduced $\mathrm{K}^{+}$and $\mathrm{Ca}^{2+}$ absorption in plants (Liu et al., 2014; Assaha et al., 2017; Isayenkov and Maathuis, 2019; Arif et al., 2020). Excess $\mathrm{Na}^{+}$influx into the cytoplasm under salt stress depolarizes the membrane potential, which activates $\mathrm{K}^{+}$outward rectifier channels, resulting in $\mathrm{K}^{+}$ efflux from root and leaf cells (Demidchik et al., 2014; Assaha et al., 2017). Regulating $\mathrm{K}^{+}$homeostasis (inhibiting $\mathrm{K}^{+}$efflux) and maintaining a high $\mathrm{K}^{+} / \mathrm{Na}^{+}$ratio are critical for salinity tolerance in plants (Janicka-Russak and Kabała, 2015; Falhof et al., 2016; Zhang et al., 2017; Yang and Guo, 2018). Studies have shown that the PM H-ATPases, $\mathrm{K}^{+}$transporters, $\mathrm{Na}^{+} / \mathrm{H}^{+}$ exchangers (NHX) and the antiporter, salt overly sensitive 1 (SOS1) act synergistically to mitigate the effects of salt stress and low $\mathrm{K}^{+}$on plant growth (Janicka-Russak and Kabała, 2015; Chakraborty et al., 2016; Falhof et al., 2016).

In this study, plants under $\mathrm{NaCl}$ stress had lower $\mathrm{Na}^{+}$and $\mathrm{Cl}^{-}$concentrations in roots than stems and leaves (Figures 5, 6), 
indicating that Huayouza 62 has a low capacity to retain saline ions in roots. In contrast, higher $\mathrm{Na}^{+}$concentrations occurred in roots than stems and leaves in potato (Solanum tuberosum L.) (Queirós et al., 2009) and pepper (Capsicum chinense Jacq.) (Emanuel et al., 2014) under $\mathrm{NaCl}$ stress. Higher $\mathrm{Na}^{+}$ concentrations in roots generally maintain osmotic potential and prevent translocation to leaves, avoiding leaf $\mathrm{Na}^{+}$accumulation (Xue et al., 2013). A study in canola seedlings showed that leaf $\mathrm{Na}^{+}$distribution was highest under $\mathrm{NaCl}$ stress but confined primarily to the leaf edge and restricted in leaf apoplasts, protecting cells from $\mathrm{Na}^{+}$stress (Gao et al., 2016). In addition, rice (Oryza sativa L.) and potato (Solanum tuberosum L.) plantlets under saline conditions accumulate $\mathrm{Cl}^{-}$to neutralize the large amounts of cations and maintain stable intracellular $\mathrm{pH}$ (Wang et al., 2011; Gao et al., 2015).

In this study, $\mathrm{NaCl}$ stress inhibited $\mathrm{Ca}^{2+}$ and $\mathrm{Mg}^{2+}$ accumulation, especially in leaves, while $\mathrm{Na}_{2} \mathrm{CO}_{3}$ stress enhanced $\mathrm{Ca}^{2+}$ and $\mathrm{Mg}^{2+}$ accumulation in stems and roots. Increasing $\mathrm{NaCl}$ significantly increased the amount of $\mathrm{Na}^{+}$in Suaeda salsa plants but decreased $\mathrm{Ca}^{2+}$ and $\mathrm{Mg}^{2+}$ concentrations (Guan et al., 2011). Other studies have shown that alkali stress significantly increased root $\mathrm{Ca}^{2+}$ and $\mathrm{Mg}^{2+}$ contents and shoot $\mathrm{Mg}^{2+}$ content (Guo et al., 2017; Wang et al., 2017). $\mathrm{Ca}^{2+}$ and $\mathrm{Mg}^{2+}$ can control the ionic balance of cells by regulating selective ion absorption and transport, reducing toxicity under saline-alkali stress (Ben-Amor et al., 2010; Feng et al., 2016; Manishankar et al., 2018). In addition, $\mathrm{Ca}^{2+}$ plays an important role in maintaining cell membrane stability and preventing membrane damage (Liu et al., 2014; Feng et al., 2016). Increased $\mathrm{Ca}^{2+}$ levels in the tissues of maize seedlings exposed to salt stress may have activated the salt overly sensitive ( $S O S)-\mathrm{Na}^{+}$system for exclusion and reduced plant damage caused by $\mathrm{Na}^{+}$toxicity (Guo et al., 2017).

Under $\mathrm{NaCl}$ stress, canola roots had significantly higher $\mathrm{K}^{+} / \mathrm{Na}^{+}, \mathrm{Ca}^{2+} / \mathrm{Na}^{+}$and $\mathrm{Mg}^{2+} / \mathrm{Na}^{+}$than stems and leaves, and the $\mathrm{K}^{+} / \mathrm{Na}^{+}$ratios in leaves and the $\mathrm{Ca}^{2+} / \mathrm{Na}^{+}$and $\mathrm{Mg}^{2+} / \mathrm{Na}^{+}$ratios in roots and stems decreased significantly at high $\mathrm{NaCl}$ concentration. Under $\mathrm{Na}_{2} \mathrm{CO}_{3}$ stress, canola leaves had a significantly higher $\mathrm{K}^{+} / \mathrm{Na}^{+}$ratio than roots and stems, which decreased with increasing $\mathrm{Na}_{2} \mathrm{CO}_{3}$ concentration; in contrast, the $\mathrm{Ca}^{2+} / \mathrm{Na}^{+}$and $\mathrm{Mg}^{2+} / \mathrm{Na}^{+}$ratios in roots increased significantly with increasing $\mathrm{Na}_{2} \mathrm{CO}_{3}$ concentration. This may be due to the high $\mathrm{pH}$ environment outside roots, therefore reducing the number of protons in external solution, weakening the exchange activity of the $\mathrm{Na}^{+} / \mathrm{H}^{+}$antiport in the root plasma membrane (Cao et al., 2020). A weakened $\mathrm{Na}^{+} / \mathrm{H}^{+}$antiport reduces the exclusion of $\mathrm{Na}^{+}$into the rhizosphere, enhancing plant $\mathrm{Na}^{+}$accumulation. In addition, studies have shown that in dicots stems, HKT, and SOS1 mediate $\mathrm{Na}^{+}$exclusion by retrieving $\mathrm{Na}^{+}$from the xylem into xylem parenchyma cells, and reducing the amount of $\mathrm{Na}^{+}$transported from xylem to the shoot (Assaha et al., 2015, 2017), which may also be an important process for rape to reduce $\mathrm{Na}$ ion content in leaves. These results indicate that maintaining a high $\mathrm{K}^{+}$concentration and $\mathrm{K}^{+} / \mathrm{Na}^{+}$ ratio in leaves and increasing the absorption of $\mathrm{Ca}^{2+}$ and $\mathrm{Mg}^{2+}$ in roots might be important mechanisms underlying alkali tolerance in canola plants.

\section{CONCLUSION}

Low salinity (50 mM NaCl and $10 \mathrm{mM} \mathrm{Na}_{2} \mathrm{CO}_{3}$ ) increased shoot growth in canola seedlings, while high salinity $(200 \mathrm{mM} \mathrm{NaCl}$ and $40 \mathrm{mM} \mathrm{Na} \mathrm{CO}_{3}$ ) significantly inhibited germination and seedling growth. The alkaline salt $\left(\mathrm{Na}_{2} \mathrm{CO}_{3}\right)$ stress restricted seed germination and seedling growth more than the neutral salt $(\mathrm{NaCl})$ stress. Under alkaline salt stress, the interaction of $\mathrm{pH}$ and salt ions rather than $\mathrm{pH}$ was the most important factor affecting seed germination and seedling growth. Ion absorption and balance in canola seedlings differed under neutral and alkaline salt stress. Under neutral salt stress, salt tolerance improved in canola due to increased root $\mathrm{K}^{+}, \mathrm{Ca}^{2+}$, and $\mathrm{Mg}^{2+}$ absorption and increased leaf $\mathrm{K}^{+}$. Under alkaline salt stress, canola maintained a high $\mathrm{K}^{+}$concentration and $\mathrm{K}^{+} / \mathrm{Na}^{+}$ratio in the leaves and increased root $\mathrm{Ca}^{2+}$ and $\mathrm{Mg}^{2+}$ uptake. Therefore, ionic regulation may be an important mechanism underlying alkaline salt tolerance in canola. However, further experiments should be conducted to assess the germination of canola seeds under individual salt ion stress conditions and the enzymatic activities and cellular damages at different stages of the germination process, and to elucidate the ion regulatory mechanisms in conjunction with transporter protein activity, in order to better understand the effects of salinity stress on canola seeds during germination and the ionic mechanisms of their response.

\section{DATA AVAILABILITY STATEMENT}

The original contributions presented in the study are included in the article/supplementary material, further inquiries can be directed to the corresponding author.

\section{AUTHOR CONTRIBUTIONS}

WW and FZ designed the research. WW, LS, YY, and YW performed the experiments. WW, JP, and LY performed the data analysis and interpretation, and prepared the figures and tables. WW, FZ, JP, and KS wrote the manuscript. All authors read, commented on- and approved the manuscript.

\section{FUNDING}

This research was financially supported by the National Natural Science Foundation of China (Grant No. 31860360) and Xinjiang Science and Technology Cooperation Program (Grant No. 2020BC001).

\section{ACKNOWLEDGMENTS}

We gratefully acknowledge the helpful comments from referees who significantly improved analysis and writing. We are very grateful to Professor Ed Barrett Lennard for his suggestions on the ideas and methods of this research. 


\section{REFERENCES}

Amor, N. B., Megdiche, W., Jimenez, A., Sevilla, F., and Abdelly, C. (2010). The effect of calcium on the antioxidant systems in the halophyte Cakile maritima under salt stress. Acta Physiol. Plant. 32, 453-461. doi: 10.1007/s11738-0090420-2

Arif, Y., Singh, P., Siddiqui, H., Bajguz, A., and Hayat, S. (2020). Salinity induced physiological and biochemical changes in plants: an omic approach towards salt stress tolerance. Plant Physiol. Biochem. 156, 64-77. doi: 10.1016/j.plaphy.2020. 08.042

Assaha, D. V. M., Ueda, A., Saneoka, H., Al-Yahyai, R., and Yaish, M. W. (2017), The role of $\mathrm{Na}$ and $\mathrm{K}$ transporters in salt stress adaptation in glycophytes. Front. Physiol. 8:509. doi: 10.3389/fphys.2017.00509

Assaha, D. V., Mekawy, A. M. M., Ueda, A., and Saneoka, H. (2015). Salinityinduced expression of HKT may be crucial for Na exclusion in the leaf blade of huckleberry (Solanum scabrum Mill.), but not of eggplant (Solanum melongena L.). Biochem. Biophys. Res. Commun. 460, 416-421. doi: 10.1016/j.bbrc.2015.03. 048

Bandehagh, A., Salekdeh, G. H., Toorchi, M., Mohammadi, A., and Komatsu, S. (2011). Comparative proteomic analysis of canola leaves under salinity stress. Proteomics 10, 1965-1975. doi: 10.1002/pmic.20100 0564

Ben-Amor, N., Megdiche, W., Jiénez, A., Sevilla, F., and Abdelly, C. (2010). The effect of calcium on the antioxidant systems in the halophyte Cakile maritima under salt stress. Acta Physiol. Plant. 32, 453-461.

Cao, Y. B., Zhang, M., Liang, X. Y., Li, F. R., Shi, Y. L., Yang, X. H., et al. (2020). Natural variation of an EF-hand $\mathrm{Ca}^{2+}$-binding-protein coding gene confers saline-alkaline tolerance in maize. Nat. Commun. 11:186.

Causin, H. F., Bordón, D. A. E., and Burrieza, H. (2020). Salinity tolerance mechanisms during germination and early seedling growth in Chenopodium quinoa Wild. genotypes with different sensitivity to saline stress. Environ. Exp. Bot. 172:103995. doi: 10.1016/j.envexpbot.2020.103995

Chakraborty, K., Bose, J., Shabala, L., and Shabala, S. (2016). Difference in root K retention ability and reduced sensitivity of K-permeable channels to reactive oxygen species confer differential salt tolerance in three Brassica species. J. Exp. Bot. 67, 4611-4625. doi: 10.1093/jxb/erw236

Demidchik, V., Straltsova, D., Medvedev, S. S., Pozhvanov, G. A., Sokolik, A., and Yurin, V. (2014). Stress-induced electrolyte leakage: the role of K-permeable channels and involvement in programmed cell death and metabolic adjustment. J. Exp. Bot. 65, 1259-1270. doi: 10.1093/jxb/eru004

Emanuel, B. Q., Ana, V. B., Ángela, K. G., Mildred, C. P., Daniela, O. C., Ileana, E. M., et al. (2014). Mechanisms of salt tolerance in habanero pepper plants (Capsicum chinense Jacq.): proline accumulation, ions dynamics, root-shoot partition and compartmentation. Front. Plant Sci. 5:605. doi: 10.3389/fpls.2014. 00605

Falhof, J., Pedersen, J. T., Fuglsang, A. T., and Palmgren, M. (2016). Plasma membrane $\mathrm{H}^{+}$-ATPase regulation in the center of plant physiology. Mol. Plant 9, 323-337. doi: 10.1016/j.molp.2015.11.002

Feng, X., Liu, W. X., Zeng, F. R., Chen, Z. H., Zhang, G. P., and Wu, F. B. (2016). $\mathrm{K}^{+}$Uptake, $\mathrm{H}^{+}$-ATPase pumping activity and $\mathrm{Ca}^{2+}$ efflux mechanism are involved in drought tolerance of barley. Environ. Exp. Bot. 129, 57-66. doi: 10.1016/j.envexpbot.2015.11.006

Food and Agricultre Organization [FAO] (2017). FAOSTAT. Available online at https://www.fao.org/faostat/en/\#data (accessed March, 2019).

Gao, H. J., Yang, H. Y., Bai, J. P., Liang, X. Y., Lou, Y., Zhang, J. L., et al. (2015). Ultrastructural and physiological responses of potato (Solanum tuberosum L.) plantlets to gradient saline stress. Front. Plant Sci. 5:787. doi: 10.3389/fpls.2014. 00787

Gao, L. M., Liu, M., Wang, M., Shen, Q. R., and Guo, S. W. (2016). Enhanced salt tolerance under nitrate nutrition is associated with Apoplast $\mathrm{Na}^{+}$content in Canola (Brassica. napus L.) and Rice (Oryza sativa L.) plants. Plant Cell Physiol. 57, 2323-2333. doi: 10.1093/pcp/pcw141

Golldack, D., Li, C., Mohan, H., and Probst, N. (2014). Tolerance to drought and salt stress in plants: unraveling the signaling networks. Front. Plant Sci. 5:151. doi: $10.3389 /$ fpls.2014.00151

Guan, B., Yu, J. B., Chen, X. B., Xie, W. J., and Lu, Z. H. (2011). "Effects of salt stress and nitrogen application on growth and ion accumulation of Suaeda salsa plants," in Proceedings of the 2011 International Conference on Remote
Sensing, Environment and Transportation Engineering, Nanjing, 8268-8272. doi: 10.1016/j.pce.2017.01.002

Guo, R., Shi, L. X., Yan, C. R., Zhong, X. L., Gu, F. X., Liu, Q., et al. (2017). Ionomic and metabolic responses to neutral salt or alkaline salt stresses in maize (Zea mays L.) seedlings. BMC Plant Biol. 17:41. doi: 10.1186/s12870-017-0994-6

Guo, R., Yang, Z. Z., Li, F., Yan, C. R., Zhong, X. L., Liu, Q., et al. (2015). Comparative metabolic responses and adaptive strategies of wheat (Triticum aestivum) to salt and alkali stress. BMC Plant Biol. 15:170. doi: 10.1186/s12870015-0546-x

Hakim, M. A., Juraimi, A. S., Hanafi, M. M., Ismail, M. R., Rafii, M. Y., Islam, M. M., et al. (2014). The effect of salinity on growth, ion accumulation and yield of rice varieties. J. Anim. Plant Sci. 24, 874-885.

Hothem, S. D., Marley, K. A., and Larson, R. A. (2003). Photochemistry in Hoagland's nutrient solution. J. Plant Nutr. 26, 845-854. doi: 10.1081/PLN120018569

Hu, H. R., Liu, H., and Liu, F. H. (2018). Seed germination of hemp (Cannabis sativa L.) cultivars responds differently to the stress of salt type and concentration. Industr. Crops Prod. 123, 254-261. doi: 10.1016/j.indcrop.2018. 06.089

Isayenkov, S. V., and Maathuis, F. J. M. (2019). Plant salinity stress: many unanswered questions remain. Front. Plant Sci. 10:80. doi: 10.3389/fpls.2019. 00080

Janicka-Russak, M., and Kabała, K. (2015). "The role of plasma membrane H-ATPase in salinity stress of plants," in Progress in Botany, eds U. Lüttge and W. Beyschlag (Cham: Springer), 77-92. doi: 10.1007/978-3-319-08807-5_3

Li, R. L., Shi, F. C., Fukuda, K. J., and Yang, Y. L. (2010). Effects of salt and alkali stresses on germination, growth, photosynthesis and ion accumulation in alfalfa (Medicago sativa L.). Soil Sci. Plant Nutr. 56, 725-733. doi: 10.1111/j.1747-0765. 2010.00506.x

Lin, J. X., Yu, D. F., Shi, Y. J., Sheng, H. C., Li, C., Wang, Y. N., et al. (2016). Saltalkali tolerance during germination and establishment of Leymus chinensis in the Songnen Grassland of China. Ecol. Eng. 95, 763-769. doi: 10.1016/j.ecoleng. 2016.07.011

Lin, J., Hua, X., Peng, X., Dong, B., and Yan, X. (2018). Germination responses of ryegrass (Annual vs. Perennial) seed to the interactive effects of temperature and salt-alkali stress. Front. Plant Sci. 9:1458. doi: 10.3389/fpls.2018.0 1458

Liu, W., Yuan, X. T., Zhang, Y. Y., Xuan, Y. N., and Yan, Y. Q. (2014). Effects of salt stress and exogenous $\mathrm{Ca}^{2+}$ on $\mathrm{Na}^{+}$compartmentalization, ion pump activities of tonoplast and plasma membrane in Nitraria tangutorum Bobr. leaves. Acta Physiol. Plant. 36, 2183-2193. doi: 10.1007/s11738-014-1595-8

Lu, H. Y., Wang, Z. Q., Xu, C. Y., Li, L. H., and Yang, C. W. (2021). Multiomics analysis provides insights into alkali stress tolerance of sunflower (Helianthus annuus L.). Plant Physiol. Biochem. 166, 66-77. doi: 10.1016/j.plaphy.2021.05. 032

Lu, N., Luo, Z., Ke, Y., Dai, L., Duan, H., Hou, R., et al. (2017). Growth, physiological, biochemical, and ionic responses of Morus alba L. seedlings to various salinity levels. Forests 8:488. doi: 10.3390/f8120488

Manishankar, P., Wang, N. L., Köster, P., Alatar, A. A., and Kudla, J. (2018). Calcium signaling during salt stress and in the regulation of ion homeostasis. J. Exp. Bot. 69, 4215-4226. doi: 10.1093/jxb/ery201

Nieves-Cordones, M., Martínez, V., Benito, B., and Rubio, F. (2016). Comparison between Arabidopsis and rice for main pathways of $\mathrm{K}(+)$ and $\mathrm{Na}(+)$ uptake by roots. Front. Plant Sci. 7:992. doi: 10.3389/fpls.2016.00992

Parihar, P., Singh, S., Singh, R., Singh, V. P., and Prasad, S. M. (2015). Effect of salinity stress on plants and its tolerance strategies: a review. Environ. Sci. Pollut. Res. 22, 4056-4075. doi: 10.1007/s11356-014-3739-1

Pivovarov, A. S., Calahorro, F., and Walker, R. J. (2019). $\mathrm{Na}^{+} / \mathrm{K}^{+}$-pump and neurotransmitter membrane receptors. Invert. Neurosci. 19:1. doi: 10.1007/ s10158-018-0221-7

Queirós, F., Fontes, N., Silva, P., Almeida, D., Maeshima, M., Gerós, H., et al. (2009). Activity of tonoplast proton pumps and $\mathrm{Na}^{+} / \mathrm{H}^{+}$exchange in potato cell cultures is modulated by salt. J. Exp. Bot. 60, 1363-1374. doi: 10.1093/jxb/ erp011

Saberi Riseh, R., Ebrahimi-Zarandi, M., Tamanadar, E., Moradi Pour, M., and Thakur, V. K. (2021). Salinity stress: toward sustainable plant strategies and using plant growth-promoting rhizobacteria encapsulation for reducing it. Sustainability 13:12758. doi: 10.3390/su132212758 
Shabala, S. (2013). Learning from halophytes: physiological basis and strategies to improve abiotic stress tolerance in crops. Ann. Bot. 112, 1209-1221. doi: $10.1093 / \mathrm{aob} / \mathrm{mct} 205$

Shahzad, B., Rehman, A., Tanveer, M., Wang, L., Park, S. K., and Ali, A. (2021). Salt stress in brassica: effects, tolerance mechanisms, and management. J. Plant Growth Regul. 1-15. doi: 10.1007/s00344-021-10338-x

Shokri-Gharelo, R., and Noparvar, P. M. (2018). Molecular response of canola to salt stress: insights on tolerance mechanisms. PeerJ. 6:e4822. doi: 10.7717/peerj. 4822

Wang, G., and Cheng, G. (2000). The characteristics of water resources and the changes of the hydrological process and environment in the arid zone of northwest China. Environ. Geol. 39, 783-790. doi: 10.1007/s002540050494

Wang, H., Wu, Z., Chen, Y., Yang, C., and Shi, D. (2011). Effects of salt and alkali stresses on growth and ion balance in rice (Oryza sativa L.). Plant Soil Environ. 57, 286-294. doi: 10.17221/36/2011-PSE

Wang, W. N. (2020). Study on Adaptability of Forage crops in Saline Alkali Farmland [D]. Wuhan: Huazhong Agricultural University.

Wang, X. P., Geng, S. J., Ma, Y. Q., Shi, D. C., Yang, C. W., and Wang, H. (2015). Growth, photosynthesis, solute accumulation, and ion balance of tomato plant under sodium-or potassium-salt stress and alkali stress. Agron. J. 107, 651-661. doi: 10.2134/agronj14.0344

Wang, X. S., Ren, H. L., Wei, Z. W., Wang, Y. W., and Ren, W. B. (2017). Effects of neutral salt and alkali on ion distributions in the roots, shoots, and leaves of two alfalfa cultivars with differing degrees of salt tolerance. J. Integr. Agric. 16, 1800-1807. doi: 10.1016/S2095-3119(16)61522-8

Xue, Z. C., Zhao, S. J., Gao, H. Y., and Sun, S. (2013). The salt resistance of wild soybean (Glycine soja Sieb. et Zucc. ZYD 03262) under $\mathrm{NaCl}$ stress is mainly determined by $\mathrm{Na}^{+}$distribution in the plant. Acta Physiol. Plant. 36, 61-70. doi: 10.1007/s11738-013-1386-7

Yang, H. C., Wang, J. Y., and Zhang, F. H. (2016). Soil aggregation and aggregateassociated carbon under four typical halophyte communities in an arid area. Environ. Sci. Pollut. Res. 23, 23920-23929. doi: 10.1007/s11356-016-7583-3

Yang, Y. Q., and Guo, Y. (2018). Elucidating the molecular mechanisms mediating plant salt-stress responses. New Phytol. 217, 523-539. doi: 10.1111/nph.14920
Zhang, H. H., Li, X., Che, Y. H., Wang, Y., Li, M. B., Yang, R. Y., et al. (2020). A study on the effects of salinity and $\mathrm{pH}$ on PSII function in mulberry seedling leaves under saline-alkali mixed stress. Trees 34, 693-706. doi: 10.1007/s00468019-01949-9

Zhang, W. W., Meng, J. J., Xing, J. Y., Yang, S., Guo, F., Li, X. G., et al. (2017). The $\mathrm{K}^{+} / \mathrm{H}^{+}$antiporter $A h N H X 1$ improved tobacco tolerance to $\mathrm{NaCl}$ stress by enhancing $\mathrm{K}^{+}$retention. J. Plant Biol. 60, 259-267. doi: 10.1007/s12374-0160905-7

Zhao, Y. G., Zhang, F. H., Yang, L., Wang, D., and Wang, W. C. (2019). Response of soil bacterial community structure to different reclamation years of abandoned salinized farmland in arid China. Arch. Microbiol. 201, 1219-1232. doi: 10.1007/ s00203-019-01689-x

Zhao, Y. Y., Lu, Z. H., and He, L. (2014). Effects of saline-alkaline stress on seed germination and seedling growth of Sorghum bicolor (L.) Moench. Appl. Biochem. Biotechnol. 173, 1680-1691. doi: 10.1007/s12010-0140956-5

Conflict of Interest: The authors declare that the research was conducted in the absence of any commercial or financial relationships that could be construed as a potential conflict of interest.

Publisher's Note: All claims expressed in this article are solely those of the authors and do not necessarily represent those of their affiliated organizations, or those of the publisher, the editors and the reviewers. Any product that may be evaluated in this article, or claim that may be made by its manufacturer, is not guaranteed or endorsed by the publisher.

Copyright (c) 2022 Wang, Zhang, Sun, Yang, Yang, Wang, Siddique and Pang. This is an open-access article distributed under the terms of the Creative Commons Attribution License (CC BY). The use, distribution or reproduction in other forums is permitted, provided the original author(s) and the copyright owner(s) are credited and that the original publication in this journal is cited, in accordance with accepted academic practice. No use, distribution or reproduction is permitted which does not comply with these terms. 